ISSN 0258-7122 (Print), 2408-8293 (Online)

Bangladesh J. Agril. Res. 42(1): 137-158, March 2017

\title{
COMPARATIVE PROFITABILITY ANALYSIS OF SHIFTING LAND FROM FIELD CROPS TO MANGO CULTIVATION IN SELECTED AREAS OF BANGLADESH
}

\author{
S. KHANDOKER ${ }^{1}$, M. A. MONAYEM MiAH ${ }^{2}$, M. A. RASHID ${ }^{3}$ \\ M. KHATUN ${ }^{1}$ AND N. D. KUNDU ${ }^{4}$
}

\begin{abstract}
Mango has emerged as an important area for diversification and as an alternative cropping pattern due to higher returns and productivity. The study was conducted in three mango growing districts, namely Chapai Nawabganj, Natore, and Rajshahi during 2014-2015 to estimate the financial benefit of shifting cereal lands to mango production, factors influencing shifting decision, and explore related problems of mango cultivation in the study areas. A total of 180 farmers taking 60 farmers from each district were selected through using multistage stratified random sampling for the study. About $49 \%$ lands were shifted to mango cultivation from cereal crops which was higher in Chapai Nawabganj (55\%) followed by Natore (48\%) district. The main reason of this shifting was reported to be higher profit compared to other crops. The average total cost of mango cultivation was Tk. 1, 33,889 per hectare. Higher cost was observed in the 16th-20th year of garden (Tk. 1, 52,010) followed by 11 th -15 th year (Tk. 1, 48,952). The average yield of mango was found to be the highest in 16th - 20th year (26.48 ton/ha) followed by 11-16th year (19.38 ton/ha). Per hectare net return from mango cultivation was Tk. 1, 75,244. Total cost of mango cultivation was $10 \%$ higher than Boro-Fallow-T.Aman cultivation. On the other hand, total cost was about $40 \%$ lower than Wheat- Jute- T.Aman, Wheat-Aus-T.Aman and Potato-Fallow-T.Aman. The net return from mango cultivation was $75 \%$ higher than other cropping patterns. The shifting of cereal lands to mango cultivation was found to be a profitable since the BCR (2.89), net present value $(\mathrm{Tk} .33,71,166)$ and internal rate of return $(39 \%)$ were very high. Relative income, farm size and education turned out to be positively significant, whereas age was negatively significant for shifting decision from cereal crops to mango cultivation. Therefore, Farmers should be motivated to cultivate mango in the fallow lands or areas where other crops are not grown well.
\end{abstract}

Keywords: Financial impact, mango, cereal crops, relative profitability and factors responsible.

${ }^{1}$ Scientific Officer, Agricultural Economics Division, Bangladesh Agricultural Research Institute (BARI), Gazipur, ${ }^{2}$ Principal Scientific Officer, Planning \& Evaluation Wing, BARI, Gazipur, ${ }^{3}$ Principal Scientific Officer, Agricultural Economics Division, BARI, Gazipur, ${ }^{4}$ Scientific Officer, Regional Agricultural Research Station, Rahmatpur, Barisal, Bangladesh. 


\section{Introduction}

Farmers' crop diversification decision is considered as one of the important economic decisions which have strong influence on their welfare in terms of income level and returns. While taking decisions farmers make choices in the context of their production possibility frontier, their expectations of relative prices and their sense of risk from both an agronomic and market perspective for various alternatives. The first decision is about the choice of number of crops. While taking decision on number of crops and level of spread in the cropping pattern, farmers also take another critical decision as to which crops to produce and how much land to be allocated to that crop. Hence, the area substitution for crop decision comes from this concept.

The sustained economic growth, rising per capita income and growing urbanization have caused a shift in the consumption patterns in favour of high value crops like fruits and vegetables from staple food crops such as rice and wheat (Joshi, 2005). In recent years, demand for fruits has grown much faster than that of food grains. Fruits play a significant role in nutritional improvement, employment generation, food and financial security of the people of Bangladesh. The consumption pattern of people in Bangladesh shows that there has been a constant increase in demand for fruits as compared to other crops. In 2009-2010, the national production and area of fruits were 1.09 million MT and 2.42 lakh hectares respectively (BBS, 2010). Among the various fruits mango is one of the most important fruit crops in Bangladesh. Mango grows widely throughout the country and is raised mostly as homestead plantations. The soil and climatic conditions of Bangladesh especially northern regions are suitable for mango cultivation. Therefore, a large number of farmers in northern region namely Pabna, Natore, Rajshahi, Chapai Nawabganj, Naogaon and Dinajpur are preferred to cultivate mango in their field. Moreover, a huge portion of lands are now substituting to mango cultivation. In 2013-2014, the area under mango cultivation was about 34632 hectares with a total production of about 992296 metric tons (BBS, 2014). The area and production of mango is increasing day by day owing to its higher returns. The growth rates of area, production and yield of mango are $2.41 \%, 4.74 \%$ and $2.33 \%$, respectively (Table 1). Due to higher returns and productivity, mango has emerged as an important area for diversification and as an alternative cropping pattern. With this backdrop, area shift in favour of fruits has been suggested as a viable option to stabilize and raise farm income, enhance agricultural growth and increase employment opportunities.

The shifting of land allocation decisions are generally analyzed at the macro level on the basis of distributive lag model that capture the role of several economic and non-economic factors in decision making. Nerlove (1958) was the first to initiate a study on this aspect where he endeavored to find the role of farmers' 
expectation of future prices in shaping their decisions on the extent of land allocation of these crops. He devised a model relating the expected normal price to "past-observed" prices. Later on, many studies used the Nerlovian model, with some modifications also, to investigate the importance of price of crop in shaping farmer's supply response behaviour (Krishna, 1963; Behrman, 1968; Askari and Cummings, 1976; De, 2005; Mythili, 2006). Deshpande and Chandrashekar (1982) made an attempt to study the role of income in the farmers' decisions at the district level, but heterogeneity in the cost across farms made it more robust to study such decisions at the micro level, viz. farmers. However, studies relating to micro-level decision for area shifting in favour of high value crops such as fruits are very scanty. Therefore, an attempt was made to focus the profitability, factors responsible and the problem of shifting of lands from cereal crops to mango cultivation in Bangladesh.

Table 1. Area, production and yield of mango in Bangladesh

\begin{tabular}{ccccc}
\hline Year & Area (ha) & $\begin{array}{c}\text { Production } \\
\text { (M.tons) }\end{array}$ & Yield (M.tons/ha) \\
\hline $2004-2005$ & 25055 & 662100 & 10.70 \\
$2005-2006$ & 25972 & 639820 & 9.97 \\
$2006-2007$ & 29109 & 766930 & 10.67 \\
$2007-2008$ & 31658 & 802750 & 10.27 \\
$2008-2009$ & 31059 & 828161 & 10.80 \\
$2009-2010$ & 32011 & 842312 & 10.65 \\
$2010-2011$ & 27466 & 889176 & 13.11 \\
$2011-2012$ & 30680 & 945059 & 12.47 \\
$2012-2013$ & 30804 & 956867 & 12.58 \\
$2013-2014$ & 34632 & 992296 & 11.60 \\
Growth rate & 2.41 & 4.74 & 2.33 \\
\hline
\end{tabular}

Source: BBS, 2011 and 2014

\subsection{Objectives}

i. To estimate and compare relative profitability of mango production with its competitive cereal crops;

ii. To estimate the financial profitability of mango production through using investment analysis; and

iii. To identify the factors influencing the shift of land from cereal crops to mango cultivation; and

iv. To derive policy implications from the above. 


\section{Methodology}

\subsection{Area Selection}

The study was conducted in three major mango growing areas, namely Chapai Nawabganj, Natore and Rajshahi. Nachol upazila from Chapai Nawabganj district, Lalpur upazila from Natore district and Poba upazila from Rajshahi district were selected for administering questionnaire survey.

\subsection{Sampling Technique and Sample Size}

A multistage stratified random sampling design was followed to collect sample farmers for this study. At first stage, three districts were selected according to the highest concentration of mango production. In the second stage, one upazila from each three districts and two blocks from each upazila were selected according to the above mentioned criteria. Finally, a total of 180 farmers taking 60 farmers from each district were randomly selected for interview. Because of common heterogeneity among agricultural household populations, it is necessary to undertake population stratification (Nyariki, 2009). Data were categorized according to year of mango cultivation. The ages of mango trees were classified as $1^{\text {st }}$ year, $2^{\text {nd }}$ year, $3^{\text {rd }}$ year, $4^{\text {th }}$ year, $5^{\text {th }}$ year, $6-10^{\text {th }}$ year, $11-15^{\text {th }}$ year, $16-20^{\text {th }}$ year and $20-25^{\text {th }}$ year.

\subsection{Method of Data Collection and Period of Study}

The study was mainly based on primary data collected during the month of January to April 2015. Field investigators under the direct supervision of the researcher collected field level cross-sectional data using pre-tested interview schedule. Necessary information regarding this study was collected based on input costs, price, yields etc.

\subsection{Analytical Techniques}

\section{a) Tabular Technique}

Collected data were edited, summarized, tabulated and analyzed to fulfill the objectives of the study. Descriptive statistics using different statistical tools like averages, percentages and ratios were used in presenting the results of the study. The profitability of mango production was examined on the basis of gross return, gross margin and benefit cost ratio analysis. Besides, the opportunity cost of family supplied labour was taken into consideration in estimating total cost. Land use cost was calculated on the basis of per year lease value of land. Project analysis and sensitivity analysis were done. Benefit Cost Ratio, Net Present Value and Internal Rate of Return were calculated (at $6.5 \%$ discount rate) with the following formulas: 
Net Present Value (NPV): The NPV of an investment is the discounted value of all cash inflows and cash outflows of the project during its lifetime. It can be computed as

$$
N P V=\sum_{t=1}^{n} \frac{B_{t}-C_{t}}{(1+r)^{t}}
$$

Benefit Cost Ratio (BCR): The BCR of an investment is the ratio of the discounted value of all cash inflows to the discounted value of all cash outflows during the life of the project. It can be estimated as follow:

$$
B C R=\sum_{t=1}^{n} \frac{\frac{B_{t}}{(1+r)^{t}}}{\frac{C_{t}}{(1+r)^{t}}}
$$

Internal Rate of Return (IRR): IRR is that rate of return at which the NPV is equal to zero. The IRR is computed as:

$$
r=\sum_{t=1}^{n} \frac{B_{t}-C_{t}}{(1+r)^{t}}=0
$$

Where,

$$
\begin{aligned}
& \mathrm{B}_{\mathrm{t}}=\text { Total benefit }(\mathrm{Tk} / \mathrm{ha}) \text { in time } \mathrm{t} \\
& \mathrm{C}_{\mathrm{t}}=\text { Total cost }(\mathrm{Tk} / \mathrm{ha}) \text { in time } \mathrm{t} \\
& \mathrm{r}=\text { Rate of interest (discount rate) } \\
& \mathrm{t}=\text { Number of years }(\mathrm{t}=1,2,3 \ldots 25)
\end{aligned}
$$

\section{Profitability analysis}

Profitability of mango and crops was analyzed to compare the return received by the farmers.

\section{Measurement of cost and return from crop cultivation}

Equations for cost analysis are as follows

$$
\begin{aligned}
& \text { Variable Cost }=\mathrm{VC}_{\mathrm{ij}}=\sum_{l=1}^{n}\left(X_{i j} P_{i j}\right) \\
& \mathrm{TVC}_{\mathrm{ij}}=\mathrm{VC}_{\mathrm{ij}}+10 \mathrm{C}_{\mathrm{ij}} \\
& \mathrm{TC}_{\mathrm{ij}}=\mathrm{TVC}_{\mathrm{ij}}+\mathrm{TFC}_{\mathrm{ij}}
\end{aligned}
$$


Where, $\mathrm{TC}_{\mathrm{ij}}=$ Total cost $(\mathrm{Tk} / \mathrm{ha})$

$\mathrm{TVC}_{\mathrm{ij}}=$ Total variable cost $(\mathrm{Tk} / \mathrm{ha})$

$\mathrm{TFC}_{\mathrm{ij}}=$ Total fixed cost $(\mathrm{Tk} / \mathrm{ha})$

$\mathrm{VC}_{\mathrm{ij}}=$ Variable cost $(\mathrm{Tk} / \mathrm{ha})$

$\mathrm{IOC}_{\mathrm{ij}}=$ Interest of operating capital $(\mathrm{Tk} / \mathrm{ha})$

$X_{\mathrm{ij}}=$ Quantity of inputs $(\mathrm{kg})$

$P_{\mathrm{ij}}=$ Price of inputs $(\mathrm{Tk} / \mathrm{kg})$

$\mathrm{j}=$ Number of crops

$\mathrm{i}=$ Number of farmers $(1.2 .3 \ldots \ldots . . \mathrm{n})$

Equations for profitability analysis

Gross return $+\mathrm{GR}_{\mathrm{ij}}=\mathrm{Y}_{\mathrm{ij}} \mathrm{P}_{\mathrm{ij}}$

Net return $=G R_{i j}-T_{i j}$

Gross margin $=\mathrm{GR}_{\mathrm{ij}}-\mathrm{VC}_{\mathrm{ij}}$

Where,

$\mathrm{GR}_{\mathrm{ij}}=$ Gross return $(\mathrm{Tk} / \mathrm{ha})$

$\mathrm{P}_{\mathrm{ij}}=$ Price $(\mathrm{Tk} / \mathrm{ha})$ of $j$ the crops received by $i$ th farmer

$\mathrm{Y}_{\mathrm{ij}}=$ Quantity $(\mathrm{kg} / \mathrm{ha})$ produced

\section{b) Statistical Technique}

\section{Multiple Regression Model}

The regression model was used to assess the factors affecting the extent of substitution by the farmers, while considering both the economic and noneconomic factors as explanatory factors. The relative price and relative income were used as explanatory variables to test whether farmers cared for only price or also the income (included price and yield) in their crop substitution decisions. The following empirical multiple linear regression function was fitted in the study.

$$
\mathrm{Y}=\mathrm{a}+\mathrm{b}_{1} \mathrm{X}_{1}+\mathrm{b}_{2} \mathrm{X}_{2}+\mathrm{b}_{3} \mathrm{x}_{3}+\mathrm{b}_{4} \mathrm{x}_{4}+\mathrm{b}_{5} \mathrm{x}_{5}+\mathrm{b}_{6} \mathrm{X}_{6}+\mathrm{b}_{7} \mathrm{X}_{7}+\mathrm{b}_{8} \mathrm{X}_{8+} \mathrm{e}
$$

Where,

$\mathrm{Y}=$ Shift of area from cereal crops to mango cultivation (ha)

$\mathrm{x}_{1}=$ Relative price of the product $(\mathrm{Tk} / \mathrm{kg})$

$\mathrm{x}_{2}=$ Relative income $(\mathrm{Tk} / \mathrm{year})$

$\mathrm{x}_{3}=$ Yield $(\mathrm{kg} / \mathrm{ha})$

$\mathrm{x}_{4}=$ Education level of the farmers (years of schooling) 


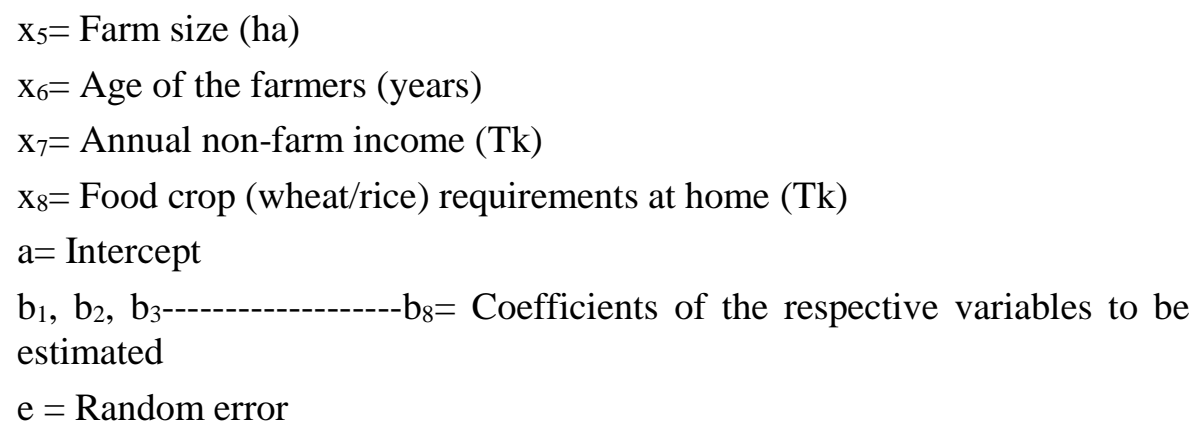

\section{Results and Discussion}

This chapter captures amount of land shifted to mango cultivation, cost and return of mango, relative profitability of mango and cereal crops cultivation, factors affecting changing cropping pattern.

\subsection{Area Substitute to Mango Cultivation}

3.1.1 Area shifted for mango cultivation: Responded farmers were asked how much land they shifted for mango cultivation from cereal crops. About $48 \%$ of their net cultivated land were shifted to mango cultivation which was higher in ChapaiNawabganj district (53\%) followed by Natore district (48\%) (Table 2). The farmers shifted $34 \%$ land of their farm size to mango cultivation. More than $50 \%$ of own cultivable land was shifted to mango cultivation. On an average, 49\% lands were shifted for mango cultivation in the study areas which was the highest in Chapai Nawabganj district (55\%) and the lowest in Rajshahi district $(45 \%)$.

Table 2. Area shifted for cultivating mango

\begin{tabular}{lcc|c|c}
\hline \multicolumn{1}{c|}{ Particulars } & $\begin{array}{c}\text { Chapai } \\
\text { Nawabganj }\end{array}$ & Natore & Rajshahi & All areas \\
\hline Area shifted for mango (ha) & 0.52 & 0.45 & 0.36 & 0.43 \\
\% of farm size & 35 & 33 & 32 & 34 \\
\% of own cultivable land & 68 & 49 & 54 & 57 \\
\% of net cultivated land & 53 & 48 & 42 & 48 \\
Average land shift (\%) & 55 & 48 & 45 & 49 \\
\hline
\end{tabular}

3.1.2 Reasons for shifting land to mango cultivation: Farmers in the study areas were asked to mention the reasons behind mango cultivation in the crops land. Respondent farmers mentioned that higher profit compared to other crops 
(73\%) was the main reason for cultivating mango (Table 3). About $61 \%$ farmers mentioned the lower price of other crops as an important factor of shifting. Easy cultivation process (47\%) was opined to be the third reasons. These responses were more or less similar in three districts. As Rajshahi and ChapaiNawabganj were in Barind region, farmers of these two districts reported that lack of irrigation facility for rice was the main reason. Some farmers (17\%) preferred mango because they could cultivate more than one crop in mango field (intercropping) which also influenced them to cultivate mango. Suitability of land for mango rather than other crops (35\%), not requiring extra care (22\%), and the lower yield of other crops $(25 \%)$ were mentioned as the reasons for cultivating mango.

Table 3. Reasons for shifting to mango cultivation

\begin{tabular}{l|c|c|c|c}
\hline \multirow{2}{*}{\multicolumn{1}{c|}{ Reasons }} & \multicolumn{4}{c}{ \% farmers responded } \\
\cline { 2 - 5 } & $\begin{array}{c}\text { Chapai } \\
\text { Nawabganj }\end{array}$ & Natore & Rajshahi & All areas \\
\hline Higher profit & 69 & 77 & 74 & 73 \\
Lower price of other crops & 63 & 59 & 61 & 61 \\
Easy cultivation process & 43 & 51 & 47 & 47 \\
Lack of irrigation facility for rice & 57 & 19 & 51 & 42 \\
Non-suitable land for other crops & 39 & 33 & 32 & 35 \\
Lower yield of other crops & 21 & 12 & 23 & 25 \\
Not required extra care & 23 & 14 & 28 & 22 \\
Can cultivate two crops at a time & 14 & 21 & 16 & 17 \\
(Intercropping) & & & & \\
\hline
\end{tabular}

\section{2 Source of Inspiration and Influence to Start Mango Cultivation for the First Time}

The sample farmers mentioned various sources that influenced or inspired them to switch over from field crops to mango cultivation for the first time. The highly reported source was neighbouring farmers (37\%) (Table 4). About 24\% farmers opined that they were influenced by their relatives to cultivate mango. In contrast, some farmers (17\%) reported that they were not influenced by anyone. They cultivated by their own experience and interest. Again, 14\% farmers were inspired by the businessmen and $8 \%$ influenced by extension worker. 
Table 4. Source of inspiration and influence to start mango cultivation for the first time

\begin{tabular}{l|ccccc}
\hline \multirow{2}{*}{ Items } & \multicolumn{4}{|c}{ \% farmers responded } \\
\cline { 2 - 5 } & Chapai Nawabganj & Natore & Rajshahi & All areas \\
\hline Neighbouring farmers & 41 & 33 & 36 & 37 \\
Relatives & 23 & 29 & 21 & 24 \\
Own experience & 18 & 15 & 19 & 17 \\
Businessman & 11 & 14 & 16 & 14 \\
Extension worker & 7 & 9 & 8 & 8 \\
Total & 100 & 100 & 100 & 100 \\
\hline
\end{tabular}

\subsection{Farmers' Perception about Cost and Return of Mango Cultivation}

The study found out farmers perception about cost of mango cultivation which is presented in Table 5. The highest percentage of farmers (56\%) mentioned that cost of mango cultivation was almost similar than competitive crops. On the other hand, $30 \%$ farmers expressed their opinion that cost of mango cultivation was lower than other crops. Only $14 \%$ farmers said that cost of mango cultivation was higher than other crops. Farmers who said that mango cultivation required higher cost also mentioned that higher profit was the main reason for cultivating mango.

Table 5. Farmers' perception on cost of mango cultivation compare to other crops

\begin{tabular}{l|ccccc}
\hline \multirow{2}{*}{ Items } & \multicolumn{4}{|c}{ \% farmers responded } \\
\cline { 2 - 5 } & Chapai Nawabganj & Natore & Rajshahi & All areas \\
\hline Almost equal & 56 & 59 & 53 & 56 \\
Lower & 33 & 28 & 30 & 30 \\
Slightly higher & 11 & 13 & 17 & 14 \\
Total & 100 & 100 & 100 & 100 \\
\hline
\end{tabular}

As farmers in the study areas were much interested in mango cultivation, it is common perception that it is highly profitable crop. Although profitability of mango cultivation was measured in this study, farmers' perception about comparative profitability was also revealed in Table 6. A large portion of the respondent farmers (49\%) told that mango was highly profitable crop compared to other crops. Besides, $41 \%$ farmers mentioned that profitability of mango cultivation was slightly higher than other crops. Very small percentage of farmers $(10 \%)$ pointed out that profitability of mango cultivation was almost equal to other crops. 
Table 6. Farmers' perception on profitability of mango cultivation compare to other crops

\begin{tabular}{l|ccccc}
\hline \multirow{2}{*}{\multicolumn{1}{c}{ Items }} & \multicolumn{4}{c}{$\%$ farmers responded } \\
\cline { 2 - 5 } & Chapai Nawabganj & Natore & Rajshahi & All areas \\
\hline Much higher & 46 & 49 & 51 & 49 \\
Slightly higher & 44 & 43 & 38 & 41 \\
Almost equal & 10 & 8 & 11 & 10 \\
Total & 100 & 100 & 100 & 100 \\
\hline
\end{tabular}

\subsection{Cost and Return of Mango Cultivation}

\section{4. 1 Intercropping with mango}

Most farmers (84\%) in the study areas practiced intercropping with mango (Table 7). In Natore district more farmers cultivated intercrop than other districts. It was found that a large number of crops were grown as intercrops in the mango field. Among the intercrops, majority of the farmers (21\%) preferred intercropping with sweet gourd followed by lentil (19\%) in all areas (Table 8). Farmers in the Chapai Nawabganj district also cultivated guava $(27 \%)$ with mango which was not found in other districts, whereas farmers in Rajshahi cultivated papaya (5\%) as intercrop. The study revealed that $16 \%$ farmers did not adopt intercrop. The main reasons for not intercropping were the reduction of mango yield and poor yields of intercrops.

Table 7. Percentage of farmers practiced intercropping in the mango field

\begin{tabular}{l|rrrrr}
\hline \multirow{2}{*}{ Items } & \multicolumn{5}{c}{ \% farmers responded } \\
\cline { 2 - 6 } & Chapai Nawabganj & Natore & Rajshahi & All areas \\
\hline Intercropping with mango & 83 & 88 & 82 & 84 \\
Not intercropping & 17 & 12 & 18 & 16 \\
Total & 100 & 100 & 100 & 100 \\
\hline
\end{tabular}

Table 8. Types of crop cultivated as intercrop

\begin{tabular}{l|c|c|c|c}
\hline \multirow{2}{*}{ Types of crop } & \multicolumn{4}{c}{ \% farmers responded } \\
\cline { 2 - 5 } & Chapai Nawabganj & Natore & Rajshahi & All areas \\
\hline Sweet gourd & 36 & 6 & 24 & 21 \\
Lentil & 11 & 35 & 10 & 19 \\
Turmeric & 7 & 19 & 16 & 14 \\
Black gram & 13 & 13 & 16 & 14 \\
Brinjal & - & 21 & 10 & 11 \\
Bitter gourd & 7 & 6 & 12 & 8 \\
Guava & 27 & - & - & 8 \\
Papaya & - & - & 14 & 5 \\
Total & 100 & 100 & 100 & 100 \\
\hline
\end{tabular}




\subsubsection{Cost of mango cultivation (including intercrops)}

The cost of production included different variable cost items like land preparation, human labour, sapling, manures, fertilizer, insecticides etc. Both cash expenditure and imputed value of family supplied inputs were included in the analysis. Besides, interest on operating capital was also considered for the estimation of cost of mango cultivation. Table 9 represents the cost of mango cultivation in different years in the study areas. The average total cost of mango cultivation in all years was found Tk. $1,33,889$ per hectare of which $57 \%$ were variable cost and the rest $43 \%$ were fixed cost. Higher cost was observed in the $16^{\text {th }}-20^{\text {th }}$ year of garden (Tk. 1, 52,010) followed by $11^{\text {th }}-15^{\text {th }}$ year (Tk. $1,48,952$ ). It might be due to the cost of human labour, cost of intercrop and higher use of insecticides. The land preparation cost and saplings costs were $0.4 \%$ and $2 \%$ of the total cost. But this two cost items were incurred only in the $1^{\text {st }}$ year. Land use cost occupied the largest share (32\%) of the total cost. On an average, labour involvement incurred $31 \%$ of the total cost. Fertilizers cost shared only $4 \%$ of the total cost and $7 \%$ of the total variable cost. On the other hand, the cost of insecticides and irrigation occupied $10 \%$ and $6 \%$ of the total cost, respectively. Farmers in the study areas spent on an average Tk. 2,599 per hectare for manures. The cost of intercrop occupied $12 \%$ of the total cost in the study areas. On an average, farmers spent Tk. 15,840 per hectare for cultivating intercrop. In the first year, responded farmers did not cultivate other crops in the mango field. That's why the cost of intercrop was considered zero in the first year. The cost of supporting stick was Tk. 8,245 per hectare in mango cultivation.

\subsubsection{Profitability of mango cultivation}

The return from mango cultivation in different years is presented in Table 10 . Farmers in the study areas obtained, on an average, 12.07 ton/ha yield. In the $1^{\text {st }}$ year and $2^{\text {nd }}$ year farmers did not find any yield. Farmers started getting yield from $3^{\text {rd }}$ year garden. In the third year, they obtained 0.38 ton/ha yield. The yield had increasing trend from $4^{\text {th }}$ year garden. The highest amount of yield was found in $16^{\text {th }}$ $-20^{\text {th }}$ year (26.48 ton/ha) old mango garden followed by $11-16^{\text {th }}$ year $(19.38 \mathrm{ton} / \mathrm{ha})$. After 20 years, yield followed decreasing trend. The farmers in the study areas found on an average 16 ton/ha yield in $21-25^{\text {th }}$ year. Likewise, the highest gross return of mango was found $16^{\text {th }}-20^{\text {th }}$ year (Tk. 7, 94,490/ha) and the lowest was found in $3^{\text {rd }}$ year (Tk. 11,430/ha). They received on an average Tk. 3, 09,133 as gross return from mango per hectare. In the second year, the gross return of intercrop was Tk. 31,546 per hectare. Highest gross return from intercrop was found in $3^{\text {rd }}$ year (Tk. 35,980/ha). The average gross return from intercrop was found Tk. 29,267 per hectare. Farmers received the highest amount of gross margin in the $16^{\text {th }}-20^{\text {th }}$ year (Tk. 7, 37,852/ha) followed by $11-15^{\text {th }}$ year (Tk. 5, 24,325/ha). Similarly, the higher amount of net return was found in the $16^{\text {th }}-20^{\text {th }}$ year (Tk. $6,75,465 /$ ha) followed by $11^{\text {th }}-16^{\text {th }}$ year $(4,63,806 / \mathrm{ha})$. Farmers gained negative gross margin and net return in the $1^{\text {st }}, 2^{\text {nd }}$ and $3^{\text {rd }}$ year of mango field. They received on an average Tk. 1, 75,244 per hectare as net return and Tk. 2, 33,039 as gross margin from mango cultivation. Farmers in the study areas spent on an average Tk. 14 for producing $1 \mathrm{~kg}$ mango. 


\subsubsection{Returns to investment in mango cultivation}

The results of project analysis are shown in Table 11 and 12 . Normally the best discount rate to use is the "opportunity cost of capital"- i.e., the profitability of the last possible investment in an economy given the total available capital (Islam etl, 2014). To calculate benefit-cost ratio (BCR) and net present worth (NPV) the cost and returns were discounted at $6.5 \%$ rate of interest.

Table 11. Financial analysis of mango cultivation

\begin{tabular}{|c|c|c|c|c|c|}
\hline Year & Gross cost $(\mathrm{Tk})$ & $\begin{array}{c}\text { Gross } \\
\text { benefit } \\
(\mathrm{Tk})\end{array}$ & $\begin{array}{c}\text { Discount } \\
\text { factor at } \\
6.5 \%\end{array}$ & PW of cost at $6.5 \%$ & PW of benefit at $6.5 \%$ \\
\hline 1 & 142963 & 0 & 0.943396226 & 134870.7547 & 0 \\
\hline 2 & 97769 & 31546 & 0.88999644 & 87014.06194 & 28075.8277 \\
\hline 3 & 113448 & 47410 & 0.839619283 & 95253.12842 & 39806.35021 \\
\hline 4 & 121402 & 69676 & 0.792093663 & 96161.7549 & 55189.91808 \\
\hline 5 & 143527 & 241114 & 0.747258173 & 107251.7238 & 180174.4071 \\
\hline 6 & 145616 & 437830 & 0.70496054 & 102653.5341 & 308652.8734 \\
\hline 7 & 145616 & 437830 & 0.665057114 & 96842.95666 & 291181.9561 \\
\hline 8 & 145616 & 437830 & 0.627412371 & 91361.27987 & 274699.9585 \\
\hline 9 & 145616 & 437830 & 0.591898464 & 86189.88667 & 259150.9043 \\
\hline 10 & 145616 & 437830 & 0.558394777 & 81311.21384 & 244481.9852 \\
\hline 11 & 148952 & 612768 & 0.526787525 & 78466.05548 & 270968.9673 \\
\hline 12 & 148952 & 612768 & 0.496969364 & 74024.58064 & 255631.1012 \\
\hline 13 & 148952 & 612768 & 0.468839022 & 69834.51004 & 241161.4163 \\
\hline 14 & 148952 & 612768 & 0.442300964 & 65881.61325 & 227510.7701 \\
\hline 15 & 148952 & 612768 & 0.417265061 & 62152.46533 & 214632.8019 \\
\hline 16 & 152010 & 827485 & 0.393646284 & 59838.17159 & 325736.3951 \\
\hline 17 & 152010 & 827485 & 0.371364419 & 56451.10527 & 307298.4859 \\
\hline 18 & 152010 & 827485 & 0.350343791 & 53255.75969 & 289904.232 \\
\hline 19 & 152010 & 827485 & 0.33051301 & 50241.28273 & 273494.5585 \\
\hline 20 & 152010 & 827485 & 0.311804727 & 47397.43653 & 258013.7344 \\
\hline 21 & 139313 & 514380 & 0.294155403 & 40979.67162 & 180249.0178 \\
\hline 22 & 139313 & 514380 & 0.277505097 & 38660.06757 & 170046.2432 \\
\hline 23 & 139313 & 514380 & 0.261797261 & 36471.76185 & 160420.9842 \\
\hline 24 & 139313 & 514380 & 0.246978548 & 34407.3225 & 151340.5511 \\
\hline 25 & 139313 & 514380 & 0.232998631 & 32459.73821 & 142774.1048 \\
\hline Total & 3548564 & 9780161 & 11.46992122 & 1779431.837 & 5150597.544 \\
\hline
\end{tabular}


Firstly, the cost and benefit streams of mango garden were discounted to find out their present worth. Dividing the present worth of the gross benefits by the present worth of the gross cost, the benefit cost ratio was found. In the study areas BCR was found 2.89 at $6.5 \%$ discount rate which is greater than unity and acceptable. The most straightforward discounted cash flow measures of the project worth are the net present worth. It is the difference between the present worth of benefits and present worth of costs. The estimated NPV of the project was Tk. 33, 71,166 per hectare which indicates that mango cultivation was profitable in the study areas.

The internal rate of return (IRR) for the investment is that discount rate which nullifies the present worth of cash flows and outflows. It represents the average earning power of the money used in the project over the project life. The IRR was found to be $39 \%$. It is highly acceptable because it is much higher than the opportunity cost of capital.

Table 12. Financial analysis of mango cultivation

\begin{tabular}{c|c|c|c|c|c}
\hline Year & $\begin{array}{c}\text { Incremental } \\
\text { benefit }\end{array}$ & $\begin{array}{c}\text { Discount factor } \\
\text { at } 35 \%\end{array}$ & $\begin{array}{c}\text { PW of benefit } \\
\text { at } 35 \%\end{array}$ & $\begin{array}{c}\text { Discount factor } \\
\text { at } 40 \%\end{array}$ & $\begin{array}{c}\text { PW of benefit } \\
\text { at } 40 \%\end{array}$ \\
\hline 1 & -142963 & 0.714286 & -102116 & 0.689655 & -98595.2 \\
2 & -66223 & 0.548697 & -36336.4 & 0.510204 & -33787.2 \\
3 & -66038 & 0.406442 & -26840.6 & 0.364431 & -24066.3 \\
4 & -51726 & 0.301068 & -15573.1 & 0.260308 & -13464.7 \\
5 & 97587 & 0.223014 & 21763.22 & 0.185934 & 18144.78 \\
6 & 292214 & 0.165195 & 48272.35 & 0.13281 & 38809.03 \\
7 & 292214 & 0.122367 & 35757.29 & 0.094865 & 27720.74 \\
8 & 292214 & 0.090642 & 26486.88 & 0.06776 & 19800.53 \\
9 & 292214 & 0.067142 & 19619.91 & 0.0484 & 14143.23 \\
10 & 292214 & 0.049735 & 14533.27 & 0.034572 & 10102.31 \\
11 & 365428 & 0.036841 & 13462.64 & 0.024694 & 9023.882 \\
12 & 365428 & 0.027289 & 9972.329 & 0.017639 & 6445.63 \\
13 & 365428 & 0.020214 & 7386.91 & 0.012599 & 4604.022 \\
14 & 365428 & 0.014974 & 5471.785 & 0.008999 & 3288.587 \\
15 & 365428 & 0.011092 & 4053.174 & 0.006428 & 2348.991 \\
16 & 675475 & 0.008216 & 5549.693 & 0.004591 & 3101.421 \\
17 & 675475 & 0.006086 & 4110.884 & 0.00328 & 2215.301 \\
18 & 675475 & 0.004508 & 3045.099 & 0.002343 & 1582.358 \\
19 & 675475 & 0.003339 & 2255.629 & 0.001673 & 1130.255 \\
20 & 675475 & 0.002474 & 1670.836 & 0.001195 & 807.3253 \\
21 & 473455 & 0.001832 & 867.5002 & 0.000854 & 404.1941 \\
22 & 473455 & 0.001357 & 642.5927 & 0.00061 & 288.7101 \\
23 & 473455 & 0.001005 & 475.9946 & 0.000436 & 206.2215 \\
24 & 473455 & 0.000745 & 352.5886 & 0.000311 & 147.3011 \\
25 & 473455 & 0.000552 & 261.1767 & 0.000222 & 105.215 \\
Total & & & 45145.31 & 2.474814 & -5493.41 \\
\hline & & & & & \\
\hline
\end{tabular}




\subsubsection{Sensitivity analysis}

Sensitivity analysis is a technique to assess the effects of adverse changes in the project. For making a valid generalization about mango cultivation sensitivity analysis was necessary. For doing this, all cost of mango cultivation were considered constant while benefit decreases at the rate of $10 \%$ or if benefit of mango remains the same but all cost increase at the rate of $10 \%$ and if benefit decrease and cost increase at the rate of $10 \%$. The results of sensitivity analysis considering the above mentioned situation is presented in Table 13. BCR of mango cultivation was found greater than one. NPV was positive at $6.5 \%$ discount rate and IRR was also higher than the opportunity cost of capital. This indicates that if the returns decrease at $10 \%$ while the cost of mango remains unchanged investment in mango is profitable from the point of view of the owner. On the other hand, if gross cost increase at $10 \%$ and returns decrease at $10 \%, \mathrm{BCR}>1$, NPV was positive and IRR was higher than the opportunity cost of capital which implies that mango cultivation is profitable.

Table 13. Result of sensitivity analysis of mango cultivation in the study areas

\begin{tabular}{l|c|c|c}
\hline \multicolumn{1}{c|}{ Situation } & $\begin{array}{c}\text { BCR at } \\
6.5 \%\end{array}$ & $\begin{array}{c}\text { NPW at } \\
6.5 \%(\mathrm{Tk} .)\end{array}$ & IRR (\%) \\
\hline Current situation & 2.89 & 3371166 & 39 \\
Increase cost 10\% but return constant & 2.68 & 3295411 & 36 \\
Decrease return 10\% but cost constant & 2.54 & 2493533 & 36 \\
Increase cost and decrease return 10\% & 2.31 & 2331941 & 35 \\
\hline
\end{tabular}

\subsection{Profitability of Cereal Crops Cultivation}

\subsubsection{Cropping pattern before shifting land to mango cultivation}

Respondent farmers in the study areas mostly cultivated two crops in a year. Some farmers cultivated three crops per year. Before shifting land to mango cultivation, they cultivated Boro, wheat, T. Aman, jute, sesame, aus, lentil, potato and some short duration vegetables. Variations found among the farmers in case of cropping pattern. A total of 19 types of cropping patterns were found in the study areas which were shifted by the 180 farmers. Major 11 cropping patterns are presented in Table 14.The highest percentage (25\%) of farmers mentioned that they followed Wheat- Jute-T.Aman cropping pattern before shifting land. The second highest percentage $(18 \%)$ of farmers followed Boro-Aus-Fallow cropping pattern which was high in Rajshahi district and low in Natore district. About 14\% farmers cultivated Boro-Fallow-T.Aman before cultivation of mango. Farmers in the Natore district mentioned that they cultivated sesame and lentil before cultivating mango which was not found in other districts. A good number of farmers in Rajshahi district cultivated potato and some short duration 
vegetables. In all areas, $13 \%$ farmers cultivated Boro-Jute-Fallow and 12\% farmers cultivated Wheat-Aus-T.Aman in their field before cultivating mango.

Table 14. Types of cropping pattern followed by the farmers before cultivating mango

\begin{tabular}{l|ccccc}
\hline \multirow{2}{*}{ Types of Cropping pattern } & \multicolumn{4}{|c}{ \% farmers responded } \\
\cline { 2 - 5 } & Chapai Nawabganj & Natore & Rajshahi & All areas \\
\hline Wheat-Jute-T.Aman & 11 & 28 & 31 & 25 \\
Boro-Aus-Fallow & 22 & 9 & 23 & 18 \\
Boro-Fallow-T.Aman & 30 & 9 & 8 & 14 \\
Boro-Jute -Fallow & 19 & 9 & 11 & 13 \\
Wheat-Aus-T.Aman & 14 & 17 & 7 & 12 \\
Wheat-Fallow-T.Aman & 5 & 2 & 8 & 5 \\
Boro-Sesame-T.Aman & - & 11 & 0 & 4 \\
Wheat-Jute-vegetables & - & - & 8 & 3 \\
Lentil-Jute-T.Aman & - & 9 & - & 3 \\
Wheat-Sesame-T.Aman & - & 34 & - & 1 \\
Potato-Fallow-T.Aman & - & - & 3 & 1 \\
Total & 100 & 100 & 100 & 100 \\
\hline
\end{tabular}

\subsection{Profitability of cereal crops cultivation}

Data in Table 15 shows the profitability of cereal crops. Total cost for WheatFallow-T.Aman cultivation was Tk. 1, 19,155 and net return was Tk. 24,983 per hectare. Per hectare total cost for Wheat-Jute-T.Aman cultivation was Tk. 1, 81,007 whereas it was Tk. 1, 64,335 for Wheat-Sesame-T.Aman cultivation. Among the cropping patterns, total cost and total variable cost for Potato-FallowT.Aman was higher than other cropping patterns which was Tk. 1, 82,735 and Tk. 1, 34,130 per hectare, respectively. Total cost and total variable cost of Wheat-Aus-T.Aman was higher than Lentil-Jute-T.Aman and Wheat-JuteVegetables. Boro- Fallow-T.Aman cultivation required Tk. 1, 13,336 as total cost which was lower than Boro-Aus-Fallow (Tk. 1, 15,593) per hectare. Highest gross return and net return was found for the cropping pattern Potato-FallowT.Aman cultivation which were Tk. 2,45,407 and Tk. 62,672 per hectare respectively. In contrast, lowest gross return and net return was found in the cropping pattern Boro-Fallow-T. Aman. On an average net return of different cropping pattern varies from Tk. 13,668 (Boro-Fallow-T.Aman) to Tk. 62,672 (Potato-Fallow-T.Aman). Highest gross margin was found for Potato-FallowT.Aman cultivation (Tk. 1, 11,277) followed by Wheat-Sesame-T.Aman (Tk. 93,976) and Wheat-Jute-T.Aman (Tk. 83,245). Return per taka invested on total 
cost and on variable cost was estimated higher in the case of Potato-FallowT.Aman which was 1.34 and 1.83 , respectively. BCR on total cost for different cropping pattern varies from 1.12 to 1.34 , whereas it was 1.36 to 1.83 on variable cost.

Table 15. Profitability of cereal crops cultivation

\begin{tabular}{|c|c|c|c|c|c|c|c|}
\hline Items & $\begin{array}{c}\text { Total } \\
\text { Cost } \\
(\mathrm{Tk} / \mathrm{ha})\end{array}$ & $\begin{array}{c}\text { Total } \\
\text { variable } \\
\text { Cost } \\
\text { (Tk/ha) }\end{array}$ & $\begin{array}{c}\text { Gross } \\
\text { Return } \\
(\mathrm{Tk} / \mathrm{ha})\end{array}$ & $\begin{array}{c}\text { Net } \\
\text { Return } \\
\text { (Tk/ha) }\end{array}$ & $\begin{array}{c}\text { Gross } \\
\text { Margin } \\
(\mathrm{Tk} / \mathrm{ha})\end{array}$ & $\begin{array}{c}\text { Return } \\
\text { per Tk. } \\
\text { invested } \\
\text { as TC }\end{array}$ & $\begin{array}{c}\text { Return per } \\
\text { Tk. } \\
\text { invested } \\
\text { as TVC }\end{array}$ \\
\hline $\begin{array}{l}\text { Potato-Fallow- } \\
\text { T.Aman }\end{array}$ & 182735 & 134130 & 245407 & 62672 & 111277 & 1.34 & 1.83 \\
\hline $\begin{array}{l}\text { Wheat-Sesame- } \\
\text { T.Aman }\end{array}$ & 164335 & 115621 & 209597 & 45262 & 93976 & 1.27 & 1.81 \\
\hline $\begin{array}{l}\text { Wheat-Jute- } \\
\text { vegetables }\end{array}$ & 143257 & 102978 & 178867 & 35610 & 75889 & 1.24 & 1.73 \\
\hline $\begin{array}{l}\text { Boro-Sesame- } \\
\text { T.Aman }\end{array}$ & 158516 & 117801 & 192463 & 33947 & 74662 & 1.21 & 1.63 \\
\hline $\begin{array}{l}\text { Wheat-Fallow- } \\
\text { T.Aman }\end{array}$ & 119155 & 86163 & 144138 & 24983 & 57975 & 1.20 & 1.67 \\
\hline $\begin{array}{l}\text { Wheat-Jute } \\
\text { T.Aman }\end{array}$ & 181007 & 133453 & 216698 & 35691 & 83245 & 1.19 & 1.62 \\
\hline Wheat-Aus-T.Aman & 179058 & 135115 & 211901 & 32843 & 76786 & 1.18 & 1.56 \\
\hline Lentil-Jute-T.Aman & 176188 & 128535 & 202099 & 25911 & 73564 & 1.14 & 1.57 \\
\hline Boro-Jute -Fallow & 117542 & 93688 & 134657 & 17115 & 40969 & 1.14 & 1.43 \\
\hline $\begin{array}{l}\text { Boro-Fallow- } \\
\text { T.Aman }\end{array}$ & 113336 & 88343 & 127004 & 13668 & 38661 & 1.12 & 1.43 \\
\hline Boro-Aus-Fallow & 115593 & 95350 & 129860 & 14267 & 34510 & 1.12 & 1.36 \\
\hline
\end{tabular}

\subsection{Relative Profitability of Mango Cultivation}

Table 16 and 17 depicted the relative profitability of mango cultivation. Total cost (TC) and total variable cost (TVC) of mango were higher than WheatFallow-T.Aman, Boro-Jute-Fallow, Boro-Fallow-T.Aman and Boro-AusFallow whereas TC and TVC of mango were lower than cost incurred for other seven cropping patterns. Total cost of mango cultivation was $10 \%$ higher than Boro-Fallow-T.Aman cultivation whereas it was on an average $40 \%$ lower than Potato-Fallow-T.Aman and Wheat-Jute-T.Aman cultivation. Moreover, mango cultivation required Tk. 13,915 more as total cost instead of cultivating BoroFallow-T.Aman (Table 26 and Table 27). For maintaining cropping pattern Wheat-Jute-T.Aman farmers required Tk. 63,997 more than mango cultivation per hectares as total variable cost. Total variable cost of mango cultivation was $34 \%$ and $32 \%$ higher than the cost incurred for Boro-Aus-Fallow and Boro- 
Jute-Fallow cropping pattern cultivation whereas it was $84 \%$ lower than WheatJute-T.Aman and Potato-Fallow-T.Aman cultivation. The gross return, gross margin and net return from mango cultivation were also higher than any of the eleven cropping patterns. Mango farmers got 59\% higher gross return compared to Boro-Fallow-T.Aman cultivation. The gross margin of mango was $85 \%$ higher than Boro-Aus-Fallow which amounted Tk. 1, 98,529 per hectare. The average net return was on an average more than $75 \%$ higher than the eleven cropping pattern. The net return of mango was $85 \%$ higher than LentilJute-T.Aman whereas it was $64 \%$ higher than Potato-Fallow-T.Aman. Likewise, the gross margin of mango was $68 \%$ higher than Lentil-Jute-T.Aman whereas it was $52 \%$ higher than Potato-Fallow-T.Aman. BCR on total cost and variable cost were also higher in mango cultivation then this eleven studied cropping patterns.

Table 16. Relative profitability of mango cultivation with other competing crops

\begin{tabular}{l|c|c|c|c}
\hline \multicolumn{1}{c|}{ Items } & $\begin{array}{c}\text { Wheat- } \\
\text { Fallow- } \\
\text { T.Aman }\end{array}$ & $\begin{array}{c}\text { Boro-Jute } \\
\text {-Fallow }\end{array}$ & $\begin{array}{c}\text { Boro- } \\
\text { Fallow- } \\
\text { T.Aman }\end{array}$ & $\begin{array}{c}\text { Boro-Aus- } \\
\text { Fallow }\end{array}$ \\
\hline Total cost lower than mango (Tk) & 8096 & 9709 & 13915 & 11658 \\
Total cost lower than mango (\%) & 6 & 7 & 10 & 9 \\
Total variable cost lower than mango (Tk) & 16707 & 24232 & 18887 & 5894 \\
Total variable cost lower than mango (\%) & 22 & 32 & 25 & 34 \\
Gross return lower than mango (Tk) & 164995 & 174476 & 182129 & 179273 \\
Gross return lower than mango (\%) & 53 & 56 & 59 & 58 \\
Gross margin lower than mango (Tk) & 175064 & 169108 & 194378 & 198529 \\
Gross margin lower than mango (\%) & 75 & 82 & 83 & 85 \\
Net return lower than mango (Tk) & 150261 & 158129 & 161576 & 160977 \\
Net return lower than mango (\%) & 86 & 90 & 92 & 92 \\
\hline
\end{tabular}

\subsection{Impact of Mango Cultivation on Income and Livelihood Pattern}

Mango cultivation has created tremendous impact to many of the respondent farmers in the study areas. Survey results exposed that $83 \%$ respondent farmers opined that switching from cereal crops to mango cultivation brought them positive impacts to some extent on household income, food intake, and livelihood improvement (Table 18). 
Table 17. Relative profitability of mango cultivation with other competing crops

\begin{tabular}{|c|c|c|c|c|c|c|c|}
\hline Items & $\begin{array}{l}\text { Wheat- } \\
\text { Jute } \\
\text { T.Aman }\end{array}$ & \begin{tabular}{|c|} 
Wheat- \\
Seasame- \\
T.Aman \\
\end{tabular} & \begin{tabular}{|c|} 
Wheat- \\
Jute- \\
vegetables
\end{tabular} & $\begin{array}{l}\text { Wheat- } \\
\text { Aus- } \\
\text { T.Aman }\end{array}$ & $\begin{array}{l}\text { Lentil- } \\
\text { Jute- } \\
\text { T.Aman }\end{array}$ & $\begin{array}{l}\text { Potato- } \\
\text { Fallow- } \\
\text { T.Aman }\end{array}$ & $\begin{array}{l}\text { Boro- } \\
\text { Sesame- } \\
\text { T.Aman }\end{array}$ \\
\hline $\begin{array}{l}\text { Total cost higher than } \\
\text { mango (Tk) }\end{array}$ & 53756 & 37084 & 16006 & 51807 & 48937 & 55484 & 41299 \\
\hline $\begin{array}{l}\text { Total cost higher than } \\
\text { mango }(\%)\end{array}$ & 40 & 28 & 12 & 39 & 37 & 41 & 31 \\
\hline $\begin{array}{l}\text { Total variable cost } \\
\text { higher than mango } \\
\text { (Tk) }\end{array}$ & 63997 & 46165 & 33522 & 65659 & 59079 & 64674 & 59539 \\
\hline $\begin{array}{l}\text { Total variable cost } \\
\text { higher than mango }(\%)\end{array}$ & 84 & 61 & 44 & 86 & 78 & 85 & 78 \\
\hline $\begin{array}{l}\text { Gross return lower than } \\
\text { mango (Tk) }\end{array}$ & 92435 & 99536 & 130266 & 97232 & 107034 & 63726 & 116670 \\
\hline $\begin{array}{l}\text { Gross return lower than } \\
\text { mango }(\%)\end{array}$ & 30 & 32 & 42 & 31 & 35 & 21 & 38 \\
\hline $\begin{array}{l}\text { Gross margin lower } \\
\text { than mango (Tk) }\end{array}$ & 149794 & 139063 & 157150 & 156253 & 15946875 & 121762 & 158377 \\
\hline $\begin{array}{l}\text { Gross margin lower } \\
\text { than mango }(\%)\end{array}$ & 64 & 60 & 67 & 67 & 68 & 52 & 68 \\
\hline $\begin{array}{l}\text { Net return lower than } \\
\text { mango (Tk) }\end{array}$ & 139553 & 129982 & 139634 & 142401 & 149333 & 112572 & 141297 \\
\hline $\begin{array}{l}\text { Net return lower than } \\
\text { mango }(\%)\end{array}$ & 80 & 74 & 80 & 81 & 85 & 64 & 81 \\
\hline
\end{tabular}

Table 18. Impact of mango cultivation to farmers

\begin{tabular}{l|c|c|c|c}
\hline \multirow{2}{*}{ Impact } & \multicolumn{4}{c}{ \% farmers responded } \\
\cline { 2 - 5 } & Chapai Nawabganj & Natore & Rajshahi & All areas \\
\hline Positive impact & 68 & 93 & 87 & 83 \\
No impact & 32 & 7 & 13 & 17 \\
Total & 100 & 100 & 100 & 100 \\
\hline
\end{tabular}

\subsection{Factors Influence Decision for Shifting Area in Favour of Mango Cultivation}

A multiple linear regression analysis was carried out for studying the influence of different factors that affect farmers to substitute their land to mango cultivation. The estimated regression coefficients and related statistics are presented in Table 19. The variations in eight independent variables included in the regression model explained nearly $80 \%$ variations in the crop substitution of mango. The $\mathrm{F}$ value was significant indicating thereby the good fit of the regression model.

The results revealed that the relative income from the crop was positive and significant in explaining the crop substitution decisions of farmers. The relative price variable came out to be insignificant. This showed that farmers, generally, 
calculate the aggregate gain from the crop in their decision rather referring to only the price of the crop. The variables age turned out to be negatively significant for shifting decision to mango cultivation. It indicated that older farmers are less likely to be interested for shifting their land as compared to young farmers. Education had positive and significant effect implying that educated farmers were more concerned about profit and income and hence they preferred to have a higher level of substitution in their cropping pattern. Farm size was positively significant which indicated that farmers with large farm size were more interested for altering their land to mango cultivation.

Table 19. Factors influencing decision for area shift in favour of mango cultivation

\begin{tabular}{lc|c|c|c}
\hline \multicolumn{1}{c|}{ Regression variable } & $\begin{array}{c}\text { Regression } \\
\text { co-efficient }\end{array}$ & t-value & $\begin{array}{c}\text { Standard } \\
\text { error }\end{array}$ & P-value \\
\hline Constant & $-0.762^{* * *}$ & 2.978 & 0.256 & 0.003 \\
Relative price (Tk/kg) & 0.018 & 1.374 & 0.013 & 0.172 \\
Relative income (Tk/farm/year) & $0.445^{* * *}$ & 2.981 & 0.149 & 0.002 \\
Yield (kg/ha) & 0.020 & 1.623 & 0.012 & 0.107 \\
Age (year) & $-0.028^{* *}$ & 2.215 & 0.013 & 0.031 \\
Education (year of schooling) & $0.034^{* *}$ & 2.045 & 0.017 & 0.043 \\
Farm size (ha) & $0.946^{*}$ & 1.935 & 0.489 & 0.055 \\
Non-farm income (Tk/farm/year) & 0.318 & 0.648 & 0.491 & 0.518 \\
Food crop requirements at home (Tk) & -0.168 & 0.345 & 0.486 & 0.731 \\
R squire & $80 \%$ & & & \\
F-values & $1.871 * * *$ & & & \\
\hline
\end{tabular}

Note: '***', '**' and '*' indicates $1 \%, 5 \%$, and $10 \%$ level of significance

\section{Conclusions and Recommendations}

The study assessed the profitability of mango cultivation in comparison of cereal crops cultivation. Respondent farmers shifted about half of their total land to mango cultivation. Although mango cultivation required slightly higher cost it received the higher net return compared to other crops. This was the main reason behind the shifting of crop land to mango cultivation. The rate of returns (i.e. BCR, NPV and IRR) indicated that mango cultivation was highly profitable for the farmers. Mango cultivation also had positive impact to household income and livelihood pattern. There was concern for household food security could hinder shift in the cropping pattern from food crop to mango. Regarding food security, majority of the farmers mentioned that they were food-self-sufficient along with increased consumption level after cultivating mango. Moreover, as the net income from mango was high so it could cover the expenditure of farm families. Farmers mentioned that as the prices of food crop were not much high so they had never faced any problem in obtaining food crops from the market. Farmers in the study areas reported some sources from which they were motivated to mango cultivation rather than cereal crops. Among them neighbouring farmers were 
opined to be as an important source of influence. This study also found out the factors that influence farmer's decision to shift from cereal crops to mango cultivation. Income, education and farm size had positive effect whereas age had negative effect to substitute their land from cereal crops to mango cultivation.The following recommendations are put forwarded for mango cultivation.

$>$ Farmers should be motivated to cultivate mango in the fallow lands or areas where other crops are not grown well.

$>$ As mango cultivation was highly profitable in the study areas, there is a tendency in the study areas to reduce crop land. Therefore, scientists should develop new cropping pattern with mango so that farmers can cultivate different food crops with mango.

\section{References}

Askari, H. and J.T. Cummings. 1976. Supply response of farmers with heterogeneous land. Indian Journal of Agricultural Economics 31(1): 13-22.

BBS. 2010. Bangladesh Bureau of Statistics, Statistical Yearbook of Bangladesh, Statistics Division, Ministry of Planning, Government of the People's Republic of Bangladesh.

BBS. 2011. Bangladesh Bureau of Statistics, Statistical Yearbook of Bangladesh, Statistics Division, Ministry of Planning, Government of the People's Republic of Bangladesh.

BBS. 2014. Bangladesh Bureau of Statistics, Statistical Yearbook of Bangladesh, Statistics Division, Ministry of Planning, Government of the People's Republic of Bangladesh.

Behrman, J.R. 1968. Supply Response in Undeveloped Agriculture: A Case Study of Four Major Annual Crops in Thailand 1937-1963. North Holland Publishing Company, Amsterdam.

De, U.K. 2005. Economics of Crop Diversification - An analysis of Land Allocation towards Different Crops. http: // mpra.u.b.uni-muenchen.de/7868/1/MPRA_ paper_7868.pdf.

Deshpande, R.S. and H. Chandrashekhar. 1982 Growth and supply response of slow growth crops: A case of pulses. Indian Journal of Agricultural Economics 37(3): 386-393.

Joshi, P.K. 2005. Crop Diversification in India: Nature, Pattern and Drivers, National Centre for Agricultural Economics and Policy research, New Delhi. http://www.adb.org/Documents/Reports/Consultant/Tar-IND-4066/Agriculture/ joshi.pdf

Krishna, R. 1963. Farm supply response in India-Pakistan: A case study of the Punjab region. The Economic Journal. 73(291): 477-487.

Mythili, G. 2006. Supply response of Indian farmers: Pre-and post-reforms. Working Paper 2006-009, Indira Gandhi Institutte for Development and Research (IGIDR), Mumbai.http://www.igidr.ac.in/pdf/publication/wp-2006-009.pdf

Nerlove, M. 1958. The Dynamics of Supply Estimation of Farmers' Response to price. John Hopkins University Press, Baltimore.

Nyariki D. M. 2009. Household data collection for Socio-economic research in agriculture: Approaches and challenges in developing countries. J. SocSci. 19(2): 91-99. 